\title{
A Deletion in the Gene for Glycoprotein Ilb Associated with Glanzmann's Thrombasthenia
}

Carol D. Burk, * Peter J. Newman," Suzanne Lyman," Joan Gill," Barry S. Coller," and Mortimer Poncz"

*Division of Hematology, The Children's Hospital of Philadelphia, Department of Pediatrics, University of Pennsylvania School of Medicine, Philadelphia, Pennsylvania 19104; ${ }^{\ddagger}$ The Blood Center of Southeastern Wisconsin, Milwaukee, Wisconsin 53233; ${ }^{8}$ Departments of Pediatrics and Anatomy and Cellular Biology, Medical College of Wisconsin, Milwaukee, Wisconsin 53233; and the "Division of Hematology, Department of Medicine, State University of New York at Stony Brook, Stony Brook, New York 11790

\section{Abstract}

The platelet fibrinogen receptor is composed of a complex of glycoproteins (GP) IIb and IIIa on the surface of platelets. Deficient function of this receptor prevents normal platelet aggregation, resulting in Glanzmann's thrombasthenia (GT). In this paper, we describe a black thrombasthenic patient who is either homozygous or hemizygous for a deletion within the GPIIb gene. Initial Western blot analysis of platelet proteins from this patient did not detect any GPIIb, but did detect small amounts of GPIIIa of normal mobility. Quantitation of vitronectin receptor (VNR) demonstrated that this thrombasthenic patient had $\sim$ 1.5-2 times the number of these receptors per platelet compared with controls, a finding that has previously been noted in other thrombasthenic patients with defects in GPIIb. Genomic Southern blot studies demonstrated a deletion in the GPIIb gene of $\sim 4.5$ kilobasepairs (kb). Analysis of the isolated GPIIb gene demonstrated that the deletion begins between two Alu repeats within intron 1 and ends in intron 9. Polymerase chain reaction (PCR) studies using platelet RNA and oligonucleotides directed to both the $5^{\prime}$ and $3^{\prime}$ ends of the GPIIb cDNA sequence easily detected GPIIb transcript, suggesting that the genomic deletion of exons 2-9 does not signifcantly decrease the level of the GPIIb mRNA. Sequence analysis of PCR-generated GPIIb cDNA showed that a cryptic AG splice acceptor sequence was being utilized, resulting in a transcript that contained a portion of introns 1 and 9, as well as having a deletion of exons 2-9. Unlike the GPIIb gene, the GPIIIa gene appears to be intact by Southern blot analysis. PCR studies using platelet RNA and oligonucleotides directed to the GPIIIa cDNA sequence demonstrated the presence of GPIIIa mRNA. In summary, the thrombasthenic state in this patient appears to be due to a GPIIb gene deletion resulting in an abnormal transcript and no detectable platelet GPIIb. Platelet GPIIIa levels were secondarily low presumably due to the known instability of GPIIIa in the absence of GPIIb. (J. Clin. Invest. 1991. 87:270-276.) Key words: Glanzmann's thrombasthenia $\bullet$ platelet $\bullet$ glycoprotein IIb $\bullet$ deletion

Address reprint requests to Dr. Mortimer Poncz, Division of Hematology, Children's Hospital of Philadelphia, 34th St. \& Civic Center Blvd., Philadelphia, PA 19104, or Dr. Peter J. Newman, Blood Center of Southeastern Wisconsin, 1701 W. Wisconsin Avenue, Milwaukee, WI 53233. 1990

Received for publication 14 May 1990 and in revised form 24 July

J. Clin. Invest.

(C) The American Society for Clinical Investigation, Inc.

$0021-9738 / 91 / 01 / 0270 / 07 \$ 2.00$

Volume 87, January 1991, 270-276

\section{Introduction}

The major fibrinogen receptor on the surface of activated platelets is a calcium-dependent heterodimeric complex of (GPIIb) ${ }^{1}$ glycoprotein IIb and GPIIIa (1-4). This receptor contains binding sites for von Willebrand factor, fibronectin, and vitronectin as well as fibrinogen (2-7). The cDNAs for near full-length GPIIb and GPIIIa have been cloned, and the encoded primary amino acid sequences deduced (8-12). Northern blot analysis of RNA from various tissues as well as immunologic and related studies have demonstrated that GPIIb is normally expressed only in platelets, whereas GPIIIa is also present on other tissues, where it is complexed with the $\alpha_{v}$ subunit to form the vitronectin receptor $\left(\alpha_{v} \beta_{3}\right)(\mathrm{VNR})(13-16)$. It is interesting that gene localization studies with the GPIIb and GPIIIa cDNAs have demonstrated that these genes are within $\sim 250$ kilobasepairs $(\mathrm{kb})$ of each other on the long arm of chromosome 17 (17). Whether this unusual proximity for two concurrently expressed genes is related to their expression in platelets is not presently known.

The GPIIb/IIIa complex is one of the integrins, a family of heterodimeric receptors that are involved in cell-cell and cellmatrix interactions $(15,16)$. Many of these receptors bind to an overlapping group of extracellular adhesion proteins, and this binding can often be competitively inhibited by Arg-Gly-Aspcontaining synthetic peptides $(7,18-21)$. A number of unique $\alpha$ (GPIIb-like) chains complex with a smaller number of more ubiquitous $\beta$ (GPIIIa-like) chains to form these receptors. Sequence analysis of the cDNAs for a number of the $\alpha$ chains have been published, and the encoded proteins share $\sim 30$ $70 \%$ amino acid identity $(9,22-29)$. The mature $\alpha$ chains are $\sim 140 \mathrm{kD}$ and many of these $\alpha$ chains consists of two disulfidelinked subchains. In an analogous fashion, sequence analysis of the cDNAs of a number of the $\beta$ chains has also been accomplished, and the encoded proteins also share amino acid homology $(10,11,30-32)$. The $\beta$ proteins are single chains of $\sim 95$ $\mathrm{kD}$, and contain four cysteine-rich domains. Unlike the close proximity of GPIIb and GPIIIa on chromosome 17, the genes for other $\alpha$ and $\beta$ chains are fairly well distributed within the human genome $(12,33,34)$.

Glanzmann's thrombasthenia is a rare autosomal recessive bleeding disorder in which platelets fail to aggregate during hemostasis secondary to disorders affecting the GPIIb/IIIa receptor (35-39). Patients may have a qualitative and/or a quantitative defect in their GPIIb/IIIa receptor. In most of these patients, the levels of GPIIb and IIIa are coordinately decreased. It is unknown if this coordinate reduction of GPIIb

1. Abbreviations used in this paper: GP, glycoprotein; PCR, polymerase chain reaction; PRP, platelet-rich plasma; VNR, vitronectin receptor. 
and GPIIIa results from decreased protein stability of nonduplexed GPIIb or GPIIIa as demonstrated in transient expression studies when the cells are transfected with only one of the two expression vectors (40), or is due to coordinate regulation of expression of these two physically close genes (12).

The specific molecular basis of the various thrombasthenic phenotypes has yet to be elucidated. Molecular studies of these patients may correlate with clinical differences between those with defects in GPIIb and those with defects in GPIIIa. Also, these studies may reveal the biological significance of the close association of these two genes on chromosome 17. In this paper, we describe a black patient with severe Glanzmann's thrombasthenia whose bleeding diathesis appears to be secondary to a deletion within the gene for GPIIb.

\section{Methods}

Clinical history. The patient is an adopted black teenage male (K.W.) with type I Glanzmann's thrombasthenia. The initial diagnosis was established by absence of platelet aggregation after stimulation with epinephrine, collagen, and ADP. Clinically, he has moderate bleeding manifested by moderate to severe epistaxis and gingival bleeding, but requires only rare platelet transfusions. The other subjects shown in Fig. 2, $A$ and $B$, include a normal volunteer and two other unrelated patients with thrombasthenia.

Polyclonal and monoclonal antibodies. Polyclonal antiserum specific for human platelet GPIIIa was raised by immunizing rabbits with a mixture of nonreduced and reduced GPIIIa that had been affinity purified by AP3-Sepharose chromatography (41). The anti-GPIIIa antibodies were affinity-purified from the antiserum on immobilized GPIIIa, and specificity was verified by immunoprecipitation and immonoclonal antibody PMI-1, specific for GPIIb (42), was kindly provided by Dr. Mark Ginsberg, Scripps Institute, La Jolla, CA. Murine monoclonal antibodies LM 609 and LM 142, specific for the VNR complex and VNR $\alpha$-subunit, respectively, $(43,44)$ were a generous gift of Dr. David Cheresh, Scripps Institute, La Jolla, CA. The affinitypurified polyclonal rabbit antibody for PECAM-1 has been previously described (45).

Platelet membrane glycoprotein analysis. Platelets from both normal control individuals and thrombasthenic K.W. were prepared by differential centrifugation of acid citrate dextrose (ACD) anticoagulated whole blood as previously described (46). Platelets were washed

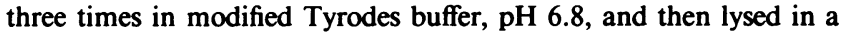
solution of $2 \%(\mathrm{wt} / \mathrm{vol}) \mathrm{SDS}, 5 \%(\mathrm{vol} / \mathrm{vol}) \beta$-mercaptoethanol, and 50 $\mathrm{mM}$ Tris, $\mathrm{pH}$ 6.8. $75 \mu \mathrm{g}$ of total protein per lane was electrophoresed through a $9 \%(\mathrm{wt} / \mathrm{vol})$ SDS polyacrylamide gel, and the proteins transferred to an Immobilon (polyvinylidene difluoride) membrane (Millipore Continental Water Systems, Bedford, MA) for subsequent Western blot analysis. The GPIIb and GPIIIa content of each platelet lysate was determined simultaneously on the same blot by coincubation of the membranes with the anti-GPIIb murine monoclonal antibody PMI-1 and the rabbit anti-GPIIla polyclonal antibody. Equal protein loading of samples was assessed by coincubation of the blots with affinity-purified antibody specific for PECAM-1, the levels of which are unaffected by the thrombasthenic phenotype (unpublished observation). Primary antibody binding was detected using a mixture of alkaline phosphatase-conjugated goat anti-rabbit and goat anti-mouse IgGs in conjunction with 5-bromo-4-chloro-3-indolyl phosphate/nitro blue tetrazolim salt substrate pair.

Platelet VNR quantitation. Blood from the patient and two controls was drawn and anticoagulated with ACD formula A (ACD-A; $1.5 \mathrm{ml}$ for $8.5 \mathrm{ml}$ blood) in Milwaukee, and then coded and shipped overnight to Stony Brook. Blood from an additional control was obtained in Stony Brook immediately after the samples arrived. The platelet counts in the samples were increased by preparing platelet-rich plasma (PRP), adding 0.1 vol of ACD-A to the PRP, centrifuging the PRP to pellet the platelets $\left(\sim 16,000 \mathrm{~g}\right.$ min at $\left.22^{\circ} \mathrm{C}\right)$, removing some of the supernatant plasma, and then resuspending the pellets to achieve platelet counts of $\sim 2 \times 10^{9} / \mathrm{ml}$. Antibody LM 142, directed against the VNR $\alpha_{\mathrm{v}}$ subunit, and antibody LM 609, directed against the VNR complex $\left(\alpha_{v} \beta_{3}\right)$, were purified by protein $\mathbf{G}$ affinity chromatography and radiolabeled with ${ }^{125}$ I using immobilized lodogen (Pierce Chemical Co., Rockford, IL). Aliquots $(0.2 \mathrm{ml})$ of the concentrated PRP were incubated with $5 \mu \mathrm{l}$ of buffer $(0.15 \mathrm{M} \mathrm{NaCl}, 0.01 \mathrm{M}$ Tris $\mathrm{HCl}, \mathrm{pH} 7.4)$ for $30 \mathrm{~min}$ and then with one of the radiolabeled antibodies for $90 \mathrm{~min}$ at $22^{\circ} \mathrm{C}$. Plateletbound antibody was then separated from free antibody by centrifugation through $30 \%$ sucrose. Nonspecific binding was determined by substituting ascites fluid containing the appropriate antibody for the $5 \mu \mathrm{l}$ of buffer in the first incubation step. Two different concentrations of each antibody were used: $\sim 110 \mathrm{ng} / \mathrm{ml}$ (range, $108-113 \mathrm{ng} / \mathrm{ml}$ ) and $\sim 313$ $\mathrm{ng} / \mathrm{ml}$ (range, $305-321 \mathrm{ng} / \mathrm{ml}$ ) for $\mathrm{LM} 142$, and $\sim 129 \mathrm{ng} / \mathrm{ml}$ (range, $112-147 \mathrm{ng} / \mathrm{ml}$ ) and $\sim 396 \mathrm{ng} / \mathrm{ml}$ (range, 388-405) for LM 609. Previous studies indicated that the $K_{\mathrm{d}}$ for LM 142 is $\sim 85 \mathrm{ng} / \mathrm{ml}$, and the $K_{\mathrm{d}}$ for LM 609 is $\sim 109 \mathrm{ng} / \mathrm{ml}$; at concentrations $\sim 10$ times the $K_{\mathrm{d}}$, the mean ( $\pm \mathrm{SD}$ ) number of LM 142 molecules that bound to normal platelets was $22 \pm 6(n=10)$, and the number of LM 609 molecules that bound was $33 \pm 11$.

Southern blot analysis. DNA was prepared from whole blood as previously described (47). A $20-\mu \mathrm{g}$ aliquot was digested at $37^{\circ} \mathrm{C}$ with 30-50 $\mathrm{U}$ of each restriction endonuclease using buffers and conditions recommended by the suppliers. Fragments were separated by electrophoresis through $0.6 \%$ agarose and transferred to Gene Screen Plus membrane (New England Nuclear, Boston, MA). Hybridizations and washing were carried out at $65^{\circ} \mathrm{C}$ according to standard conditions suggested by the manufacturer. A 3.3-kb full-length GPIIb cDNA (9), and the $5^{\prime}$ and $3^{\prime}$ Eco RI fragments of the GPIIIa cDNA (11), comprising the full-length cDNA, were used as probes for the initial genomic Southern blot analyses. A 2.4-kb Bam HI/Bgl II GPIlb genomic fragment, containing exons 5-12 (Fig. $2 C$ ) (48), was used as a probe to further localize the deletion on genomic Southern blot analysis. Probes were radiolabeled with $\alpha-{ }^{32} \mathrm{P}$ dCTP using random oligo primers and Klenow as described previously (49).

Construction and screening of the thrombasthenic genomic library. Using $110 \mu \mathrm{g}$ of genomic DNA isolated from the thrombasthenic patient, a lambda genomic library was constructed (50). The DNA was partially digested with Sau IIla. Fragments from 15 to $24 \mathrm{~kb}$ in length were selected on a sucrose gradient, ligated to EMBL $3 \mathrm{~A}$ arms, and packaged using the Gigapack Plus Cloning System (Stratagene, La Jolla, CA), and the resultant phage were used to infect NM539 bacteria. Screening of the library with radiolabeled GPIIb cDNA was as previously described (49).

Characterizing the deletional breakpoint. Positive clones were plaque-purified, and the inserts were characterized by restriction analysis and Southern blotting studies using radiolabeled GPIIb cDNA probe. An Sst I restriction fragment which was anticipated to contain the deletional breakpoint was isolated and subcloned into M13 mp18 phage. Clones containing the insert in complementary orientations were identified using an $\mathrm{S} 1$ nuclease protection assay (51). In addition, S1 nuclease protection assays were performed between these singlestranded clones and the complementary normal $4.8-\mathrm{kb}$ Bam $\mathrm{HI}$ fragment that contains exons 5-13 (Fig. $2 C$ ) (51) to localize the deletional breakpoint within the Sst I fragment.

Sequence analysis was performed using the Sanger method (52) and the Sequenase enzyme protocol (United States Biochemical Corp., Cleveland, $\mathrm{OH}$ ). The antisense 15 nucleotide oligonucleotide (TGCAGGAACAATAC) used as a primer for sequence analysis across the deletional breakpoint is complementary to bases $1108-1122$ of the fulllength GPIIb cDNA and is located within exon 12 (48).

Platelet mRNA studies. Total cellular RNA was prepared from human platelets, and specific regions of mRNA were reverse transcribed into CDNA and then amplified using the polymerase chain reaction (PCR) technique as previously described $(46,53)$. Oligonucleotide primers were used at final concentrations of $200-500 \mathrm{nM}$ except for reaction tubes containing more than one primer pair (multiplex PCR), 
in which all primer concentrations were limited to $100 \mathrm{nM}$ to avoid artifacts associated with primer complementarity. PCR primers 1-4 correspond to sequences of GPIIb cDNA (9), whereas primers 5 and 6 correspond to sequences of GPIIla cDNA (10). Following amplification, PCR reactions products were resolved on GTG agarose gels (FMC Corp., Rockland, ME) recovered using GENECLEAN (Bio 101 Co., La Jolla, CA), and sequenced directly using T7 DNA polymerase (Sequenase $^{\mathrm{TM}}$; United States Biochemical Corp., Cleveland, $\mathrm{OH}$ ) according to manufacturer's recommendations. In some instances cDNA fragments were blunt-end ligated into the Eco RV-cut plasmid vector pGEM-5Zf for restriction site and DNA sequence analyses.

Oligonucleotides used for these studies include the GPIIb oligonucleotides 1 (GGCCAGAGCTTGTGTCCACTCTGC) for GPIIb, bases 4-26 (sense), 2 (CCATATACAGTGGAGCGCCCACC) for GPIIb, bases 1037-1015 (antisense), 3 (GAGCTGCAGATGGACGCAGCCAAC) for GPIIb, bases 1988-2011 (sense), 4 (CAGGAAGGCCAGCACCGTGACCATG) for GPIIb, bases 2821-2797 (antisense), 5 (CATGTGTGCCTGGTGCTCTGATG) for GPIIIa, bases 161-183, and 6 (CACCTGGTCAGTTAGCGTCAGCAC) for GPIIIa, bases 698-674 (antisense). These primers are schematically shown at the top of Fig. 4.

\section{Results}

Immunoblot analysis of GPIIb and GPIIIa. The thrombasthenic phenotype of patient K.W. was confirmed by immunoblot analysis using a mixture of anti-GPIIb, anti-GPIIIa and antiPECAM-1 antibodies. As shown in Fig. 1, K.W. had undetectable levels of GPIIb. Significantly, GPIIIa was present at approximately $1-5 \%$ of normal levels, and that which was present comigrated with normal GPIIIa. That approximately equal amounts of protein were loaded in each lane was demonstrated by immunostaining with anti-PECAM-1, which is known to be present in normal amounts in thrombasthenic platelets (Newman, P.J., unpublished observations), consistent with a primary defect in GPIIb, with GPIIIa levels being secondarily affected.

Platelet VNR quantitation. The results of the antibody LM 142 and LM 609 binding studies are presented in Table I. The values for the control samples drawn in Milwaukee were similar to those of the fresh sample drawn in Stony Brook, suggesting that the lag time involved in transporting the samples did not significantly affect the results. The values for the higher

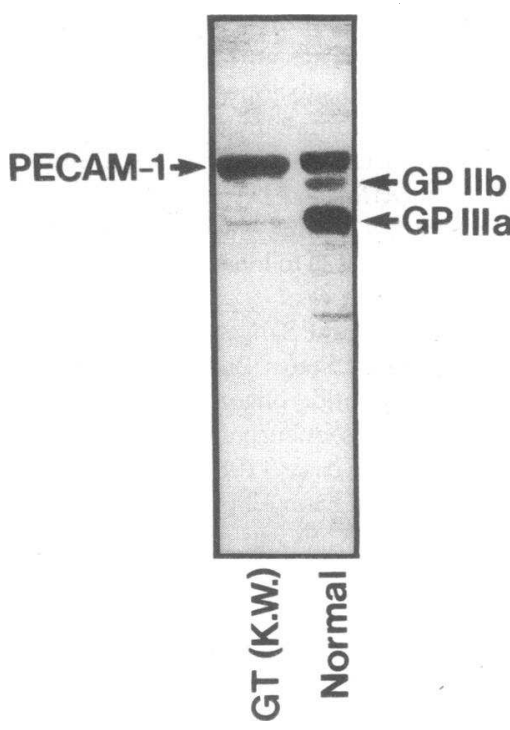

Figure 1. Immunoblot analysis of normal and thrombasthenic K.W. whole platelet lysates. $75 \mu \mathrm{g}$ platelet protein was electrophoresed and immunoblotted as described in Methods. Note the presence of GPIIIa in small amounts in the thrombasthenic lysate. Overloading of this sample on other gels (not shown) indicate that $1-5 \%$ of the normal GPIIIa content is present in the K.W. lysate. doses of antibody binding to control platelets were also similar to the values previously obtained using near-saturated concentrations of the antibodies with other normals drawn fresh at Stony Brook (LM $142=22 \pm 6$ molecules per platelet, and LM $609=33 \pm 11$ molecules per platelet) .

Each of the values for the patient's platelet exceeded the highest value for any of the controls; the increases in binding for both antibodies were concordant (LM 142, 180\% control; LM 609, 200\%). These results indicate that at least some of the GPIIla identified by immunoblot analysis is associated with the $\alpha_{\mathrm{v}}$ subunits to form VNR. Since this indicates that the patient's GPIIla is able to complex with an $\alpha$ subunit normally, it suggests that the patient's defect would be in the GPIIb unit. Analysis of other patients with thrombasthenia have shown that in those patients with a GPIIb defect, that the number of anti-VNR antibody bound per platelet is similarly increased in patients whose defects are in GPIIb (54-56).

Southern blot analysis of the genes for GPIIb and GPIIIa. Southern blot analyses of genomic DNA from patient K.W., a normal control, and two additional thrombasthenic patients were performed using restriction endonucleases Hind III, Sst I, and Bam HI, and compared with blots of a panel of normal controls. Blots hybridized with radiolabeled full-length GPIIla cDNA demonstrated completely normal banding patterns in all four patients (data not shown). The identical blots were also hybridized with radiolabeled full-length GPIIb cDNA (Fig. 2, $A$ and $B$ ). The normal control and the two other thrombasthenic patients demonstrated the anticipated restriction pattern. However, patient K.W. had an absence of a 13.9-kb Hind III fragment with the appearance of a new 9.4-kb fragment (Fig. 2 B), an absence of a 9.6-kb Sst I fragment with the appearance of a new 5.0-kb fragment (Fig. $2 A$ ), and an absence of a 4.8-kb Bam $\mathrm{HI}$ fragment (data not shown). These findings are consistent with a homozygous or hemizygous 4.5-5.0-kb deletion encompassing a major portion of the coding regions of the absent Bam $\mathrm{HI}$ fragment and localizes the deletion to a region beginning downstream of exon 1 at its $5^{\prime}$ end and the exon 13-18 cluster at its $3^{\prime}$ end in Fig. 2 B. Further localization of the deletion was accomplished by hybridizing the same Hind III/Bam HI blot to radiolabeled 2.4-kb Bam $\mathrm{HI} / \mathrm{BgI}$ II genomic GPIIb fragment (which includes exon 5-12 in Fig. $2 \mathrm{~B}$ ). Results of this experiment (data not shown) revealed that the large 9.4-kb Hind III fragment is present, and the 4.8-kb Bam HI fragment is absent. A new 9.8-kb Bam HI fragment was now detected that was not appreciated with the GPIIb cDNA probe. This new band must

Table I. Quantitation of Platelet Vitronectin Receptor Subunits

\begin{tabular}{|c|c|c|c|c|}
\hline \multirow[b]{2}{*}{ Patient } & \multicolumn{2}{|c|}{$\begin{array}{c}\text { Anti-VNR } \alpha \text { chain } \\
\text { antibody }\end{array}$} & \multicolumn{2}{|c|}{$\begin{array}{c}\text { Anti-VNR complex } \\
\text { antibody }\end{array}$} \\
\hline & low $\mathrm{Ab}$ & high $\mathbf{A b}$ & low $\mathrm{Ab}$ & high Ab \\
\hline \multicolumn{5}{|l|}{ Controls: } \\
\hline Milwaukee 1 & $21^{*}$ & 37 & 33 & 57 \\
\hline Milwaukee 2 & 21 & 31 & 31 & 31 \\
\hline Stony Brook & 25 & 21 & 36 & 58 \\
\hline Mean & 22 & 30 & 33 & 49 \\
\hline K.W.: & 39 & 53 & 60 & 105 \\
\hline Percentage of control & 157 & 252 & 167 & 182 \\
\hline
\end{tabular}

* Antibody molecules bound per platelet. 

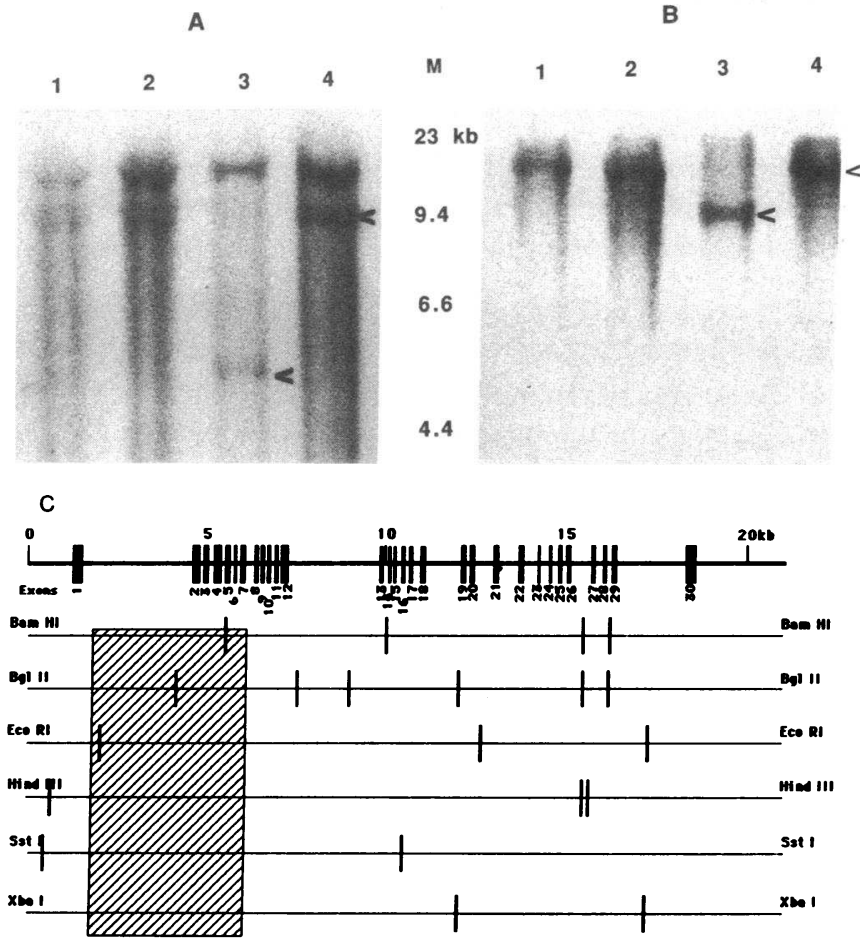

Figure 2. GPIIb genomic analysis. $(A)$ Southern blots of Sst I digested genomic DNA probed with full-length GPIIb cDNA. 1 , normal control; 2 and 4, other thrombasthenic patients; and 3, K.W. The band affected by the deletion is indicated by arrowheads. $M, \lambda$ Hind III marker. $(B)$ Same as $(A)$ but represents Hind III genomic digest. This Hind III gel is sized to the marker shown on the left. $(C)$ Restriction map of the GPIIb gene as previously published (48) with the deleted region demonstrated as a hatched region. A stick figure for the GPIIb gene is shown at the top, and the relevant restriction sites are noted below.

result from a deletion of the Bam $\mathrm{HI}$ site near exon 5 , and further localizes the deletion to within a region that extends downstream of exon 1 to near exon 12 in Fig. $2 C$.

In order to define the deletion endpoints a partial Sau IIIa genomic library of the patient's DNA was constructed and screened. Three positive clones were isolated after screening a total of 400,000 plaques with the full-length GPIIb cDNA probe. Restriction analysis demonstrated that all three clones included a 5.3-kb Sst I fragment. This fragment would be expected to encompass the deleted area, and represents a 4.6-kb shortening of the normal Sst I fragment shown in Fig. $2 B$.

Initial localization of the deletional breakpoint was done using an S1 nuclease protection assay between single-stranded M13 phage containing the patient's truncated Sst I fragment and single-stranded M13 phage containing the normal 4.8-kb Bam HI genomic fragment which contains exons 5 through 13 in Fig. $2 C$. A fragment of $\sim 3.3 \mathrm{~kb}$ was protected, placing the $3^{\prime}$ deletion breakpoint within the cluster of exons 8-12 (data not shown).

Sequence analysis across the deletional breakpoint was accomplished using single-stranded DNA of the 5.3-kb Sst I thrombasthenic insert in M13 mp18 phage as template and a complementary antisense oligonucleotide to a region of exon $12(48)$ as primer as described in Methods. The upstream breakpoint of the deletion is in intron 1 , and is $483 \mathrm{bp} 3^{\prime}$ to exon 1 and is within the 5 end of the second of a pair of direct

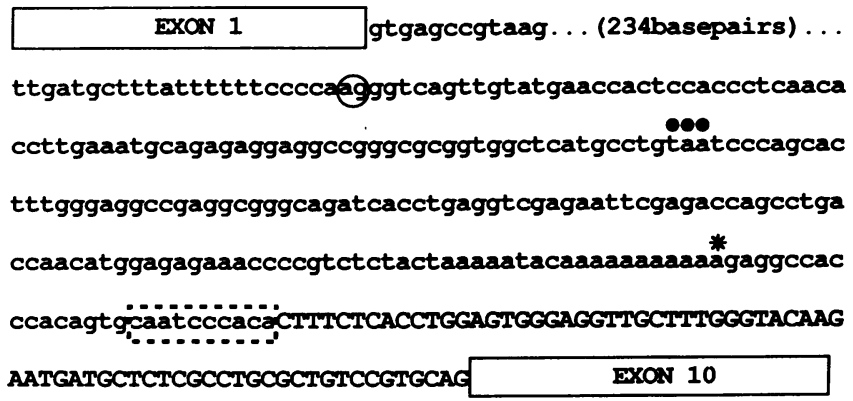

Figure 3. Sequence analysis of deletion breakpoint. Sequence analysis of the interval between exon 1 and exon 10 of GPIIb in K.W. Exons are indicated as open boxes. Sequence $5^{\prime}$ to the deletion and corresponding to normal intron 1 is shown in small letters, while those $3^{\prime}$ to the deletion and corresponding to normal intron 9 is shown as capital letters. Between these two sequences is a short region of 10 bases that does not correspond to either and is boxed with a dashed line. The site of a difference in the length of a poly A stretch (20 in normal and 11 in K.W.) is indicated by an asterisk. The cryptic splice acceptor site is circled and splices in K.W. to the normal splice site preceding exon 10 (see Results). The resulting in-frame TAA termination codon is dot overlined.

Alu repeats (57) (Fig. 3). The only difference between the published normal sequence and K.W.'s in this region is the length of the poly A region at the end of the Alu repeat, which is 20 in the normal and 11 in K.W. (asterisk in Fig. 3). This difference may represent a polymorphism. At the $3^{\prime}$ end, the deletion ends in intron 9 , and is $69 \mathrm{bp} 5^{\prime}$ to the start of exon 10 , and $1551 \mathrm{bp} 5^{\prime}$ to an Alu repeat in intron $12(48)$. Between the two breakpoints is an additional $10 \mathrm{bp}$ that has only limited homology with either the normal $5^{\prime}$ or $3^{\prime}$ GPIIb sequence (dash-boxed in Fig. 3). The deletion includes $2.0 \mathrm{~kb}$ of intron 1 that has yet to be sequenced (48), so that the exact size of the deletion is not known but is estimated to be $4.5 \mathrm{~kb}$.

$P C R$ analysis of normal and $K . W$. platelet RNA transcripts. To assess the effect on transcription and mRNA processing of this major deletion in the GPIIb gene, we initially attempted without success to analyze platelet GPIIb and GPIIla mRNA by Northern blot analysis (data not shown). Platelets contain only small amounts of residual RNA, and the inability to demonstrate the presence of GPIIb and GPIIIa RNA might simply reflect this technical problem in obtaining sufficient RNA. We, therefore, used the more sensitive approach of reverse transcribing the RNA into single-stranded complementary DNA followed by PCR amplification $(46,53)$. This approach allowed us to analyze whether there is detectable GPIIb mRNA in K.W.'s platelets and to study the effect of the genomic deletion on intron processing. Several primer pairs, delineated in Methods, were used. The results of studies with normal and K.W.'s total platelet RNA using the two primer pairs for GPIIb mRNA and the one pair for GPIIIa that are schematically illustrated at the top of Fig. 4 are discussed below.

Primer pairs $3+4$ normally result in an amplified DNA segment of $833 \mathrm{bp}$ and $5+6$ normally result in an amplified DNA segment of $537 \mathrm{bp}$. PCR analysis of the patient's platelet RNA with both of these oligonucleotides demonstrate that both GPIIb and GPIIIa mRNAs are detectable in K.W.'s platelet RNA with the same size and quantity of final PCR product as in the normal control (Fig. $4 A$ ). Primer pair $1+2$ was 

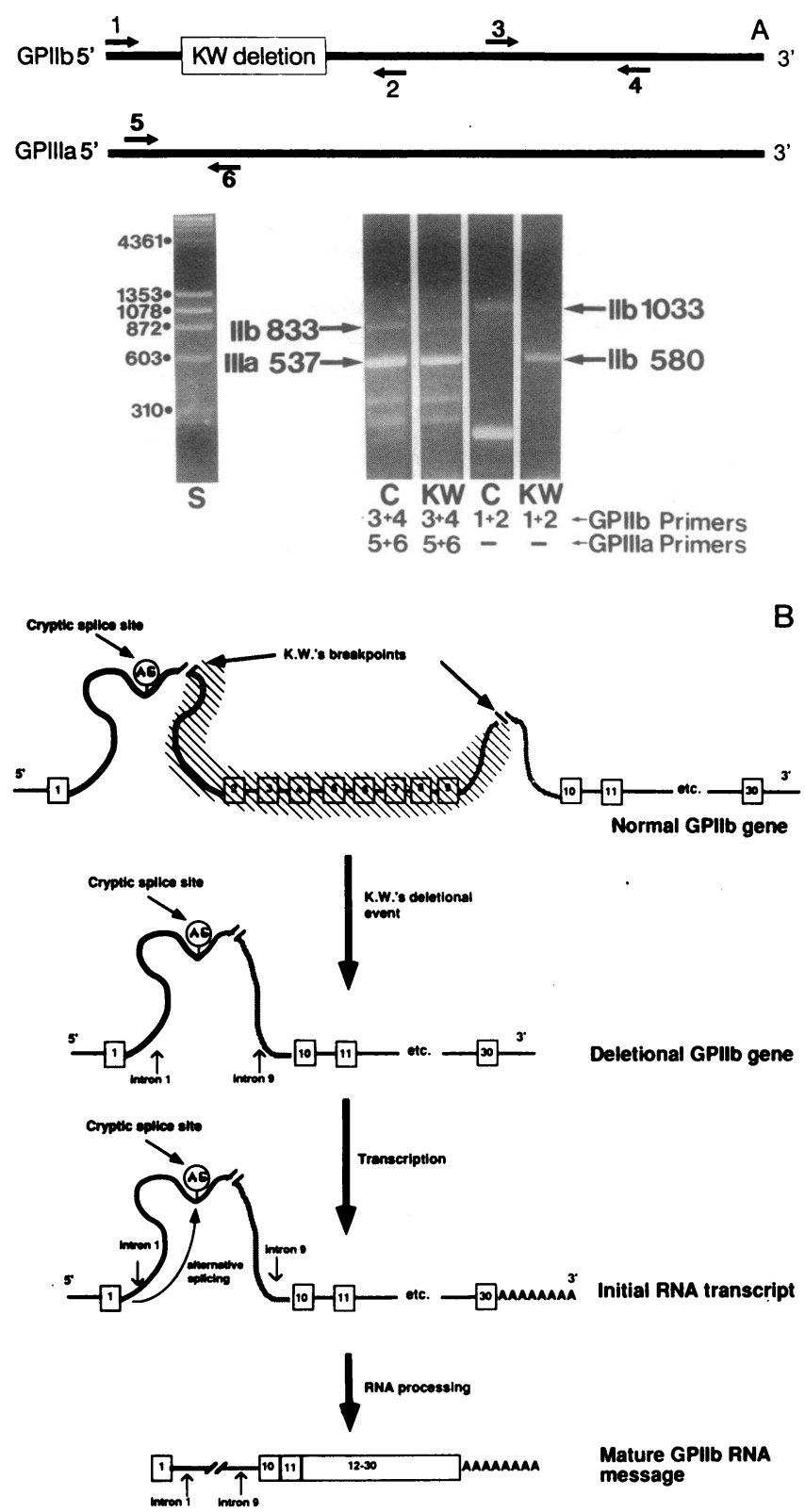

Figure 4. PCR analysis of cDNA derived from total platelet RNA. $(A)$ A normal control $(C)$ was compared with patient K.W. A multiplex analysis with GPIIb primers $3+4$ and with GPIIIa primers $5+6$ are shown in the middle set of lanes of the agarose gel. At the right are two lanes with GPIlb primers $1+2$. The sites and orientation of these primers are shown in schematic form at the top of the figure. At the left is a standard size marker lane $(S)$ of lambda phage digested with Hind III and $\phi X$ phage digested with Hae III. (B) Schematic representation of the normal sequence in the region of interest of the GPIIb gene with the DNA deleted shown as the hatched on the top line. Exons are indicated as open numbered boxes. The 5'- and 3'flanking regions and the introns are indicated as a line. Intron 1 is shown as a heavier black line and intron 9 is shown as a heavier grey line. The cryptic splice acceptor site is indicated as an encircled $A G$ The breakpoints of deletion are indicated by the break in the introns bordered by two short diagonally placed lines, and the actual DNA sequence deleted is shown under a diagonally shadowed region. Below is a schematic representation of the GPIIb gene in K.W. in this same region, and beneath this is a schematic representation of the initial RNA transcript of this partially deleted gene in the region of interest, with the breakpoint point of the deletion indicated. At the designed to amplify a region surrounding the deletion indicated from the genomic cloning experiments, with primer 1 located within exon 1 of the GPIIb gene, and primer 2 corresponding to a region on the antisense strand within exon 12 . The PCR product expected from this primer pair is $1,033 \mathrm{bp}$, and this band is observed in studies with normal platelet RNA (Fig. $4 \mathrm{~A}$ ). In light of the fact that exons 2-9 are deleted in the genome of K.W., we expected a 296-bp PCR product using K.W.'s platelet RNA as starting material, assuming that exon 1 spliced to the next normal splice acceptor site which is found preceding exon 10 . Unexpectedly, the PCR product obtained was $580 \mathrm{bp}$. Sequence analysis demonstrated that this $580-\mathrm{bp}$ cDNA band encoded parts of intron 1 and 9 , consistent with the utilization of a cryptic AG splice acceptor located within a pyrimidine-rich region of intron 1 (48) (circled in Figs. 3 and 4 $B)$. This splice acceptor site probably becomes exposed due to secondary structure modifications in the heteronuclear GPIIb RNA transcribed from the deleted GPIIb gene. Thus a pseudoexon is formed that contains a portion of introns 1 and 9 as well as all of exon 10 (Fig. $4 \mathrm{~B}$ ). The resulting GPIIb mRNA has an in-frame TAA termination codon 26 triplets downstream from the end of exon 1 (dot overlined in Fig. 3), resulting in a very truncated GPIIb protein. Even if sufficient GPIIb mRNA reaches the cytoplasm in the developing megakaryocyte, no full-length GPIIb product would be available to complex with the GPIIIa.

\section{Discussion}

Although previous studies suggest that Glanzmann's thrombasthenia is due to a heterogeneous group of defects, the molecular basis for this heterogeneity has only begun to be defined on a molecular level. It is very likely that this disease will prove to be heterogeneous with many different mutations being defined in different ethnic groups and in patients with different clinical severity much as has already been demonstrated with the thalassemias (58). The classical division into the two categories of severely GPIIb/IIIa-deficient patients (type I) and those less deficient (type II) will be replaced by a precise definition of defects and correlation with phenotype. Recently, a patient heterozygous for an insertion in the GPIIla gene has been reported (59). In this report, we describe a black thrombasthenic patient homozygous or hemizygous for a 4.5-kb deletion in the $5^{\prime}$ region of the GPIIb gene. This deletion eliminates exons 2-9. Because natural relatives of this adopted subject are not available, further family studies could not be done to distinguish between the two possibilities.

As noted previously, the GPIIb gene is rich in Alu repeats, having at least 10 repeats distributed throughout its $17-\mathrm{kb}$ sequence (48). All of these repeats are oriented in the same direction. At its $5^{\prime}$ end, the deletion in K.W. occurs within a direct Alu repeat. However, most deletions for which the end-points of the breakpoint have been defined (e.g., the thalassemias [58]) do not involve Alu repeats. The fact that only one end of this patient's deletion occurs within a direct Alu repeat suggests that a nonhomologous crossover involving Alu repeats could not have caused this patient's deletion.

The large deletion in the GPIIb gene in K.W. results in an abnormal transcript that is missing exons $2-9$, but contains

bottom is a schematic representation of the final mature GPIIb RNA. This mRNA has exon 1, a portion of introns 1 and 9 , and exons 10-30. 
portions of introns 1 and 9. This RNA is processed in the nucleus, using the normal exon 1 splice donor and a cryptic splice acceptor site in intron 1 to form a GPIIb mRNA species that is missing exons 2-9 and portions of introns 1 and 9 as well as exon 1 and exons 10-30. This mRNA species is sufficiently stable as to yield PCR-amplifiable GPIIb cDNA fragment from platelet total RNA. Unfortunately, while the amount of total RNA that can be isolated from platelets is sufficient for demonstrating a qualitative defect in K.W.'s GPIIb mRNA, it is insufficient to quantitate the relative level of his GPIIb mRNA beyond stating that this mRNA species was present in platelets in sufficient amounts to be detectable by PCR amplification.

In contrast to the GPIlb gene in this patient, the GPIIIa gene appears intact. Within the limitations of restriction endonuclease mapping of genomic DNA, the GPIIla gene does not appear to have a deletion or rearrangement. Transcription from this gene has been shown by PCR analysis for GPIIIa using the patient's platelet RNA. This mRNA is translated into GPIIIa with normal mobility as demonstrated on Western blot analysis. However, the level of this platelet GPIIIa protein is only $1-5 \%$ of normal. This low level of GPIIla expression is most likely due to instability of unduplexed GPIIIa as shown by both pulse-chase studies of human megakaryocytes and megakaryocyte-like cell-lines (40), and by transient expression studies of recombinant GPIIb and IIIa in COS cells where transfection of either GPIIb or IIIa alone did not result in any surface expression, while cotransfection studies resulted in completion of GPIIb maturation and the expression of the GPIIb/IIIa complex on the cell surface (60). A small portion of platelet GPIIIa protein does form stable duplexes with VNR $_{\alpha}$ $(61,62)$. As in other patients with a deficiency in GPIIb, newly synthesized GPIIIa complexes with the small internal pool of $\mathrm{VNR}_{\alpha}$ chains, resulting in an increased level of VNR on the platelet surface, rescuing the $1-5 \%$ of GPIIIa molecules observed in such platelets. To explain why patients with defects in GPIIb may have an increase in platelet VNR, one can postulate

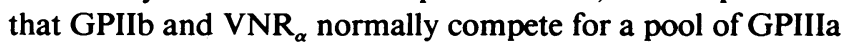
molecules, and those GPIIb and $\mathrm{VNR}_{\alpha}$ molecules that fail to complex with a GPIIIa molecule are proteolytically digested. If GPIIb synthesis is impaired, then there will be fewer GPIIb molecules to compete for GPIIIa, and thus it is more likely that the $\mathrm{VNR}_{\alpha}$ molecules synthesized will join with GPIIIa molecules and be transported to the platelet membrane as VNR. Thus, the small amount of GPIIIa seen on the Western blot may be due solely to the presence of GPIIIa within the platelet VNR or be due in part to residual unduplexed cytoplasmic GPIIIa.

\section{Acknowledgments}

The authors thank Dr. M. Ginsberg and Dr. D. Cheresh for their generous contributions of antibody reagents, Padmini Malladi and Dr. Eric Rappaport for excellent technical advice, and Dr. Saul Surrey and Dr. Elias Schwartz for useful discussions during the preparation of this manuscript.

This work was supported by grants from the National Institutes of Health (HL-40387, HL-07439, HL-38166, and HL-19278) and the March of Dimes.

\section{References}

1. Jennings, L. K., and D. R. Phillips. 1982. Purification of glycoproteins IIb and III from human platelet plasma membranes and characterization of a calcium-dependent glycoprotein IIb-III complex. J. Biol. Chem. 257:10458-10466.
2. Kunicki, T. J., D. Pidard, J.-P. Rosa, and A. T. Nurden. 1981. The formation of $\mathrm{Ca}+2$-dependent complexes of platelet membrane glycoproteins IIb and IIIa in solution as determined by crossed immunoelectrophoresis. Blood. 58:268278.

3. Bennett, J. S., J. A. Hoxie, S. F. Leitman, G. Vilaire, and D. B. Cines. 1983 Inhibition of fibrinogen binding to stimulated human platelets by a monoclonal antibody. Proc. Natl. Acad. Sci. USA. 80:2417-2421.

4. Bennett, J. S., G. Vilaire, and D. B. Cines. 1982. Identification of the fibrinogen receptors on human platelets by photoaffinity labeling. J. Biol. Chem. 257:8049-8054.

5. Ginsberg, M. H., J. Forsyth, A. Lightsey, J. Chediak, and E. F. Plow. 1983. Reduced surface expression and binding of fibronectin by thrombin-stimulated thrombasthenic platelets. J. Clin. Invest. 71:619-625.

6. Ruggeri, Z. M., R. Bader, and L. DeMarco. 1982. Glanzmann thrombasthenia: deficient binding of von Willebrand factor to thrombin-stimulated platelets. Proc. Natl. Acad. Sci. USA. 79:6038-6041.

7. Pytela, R., M. D. Pierschbacher, M. H. Ginsberg, E. F. Plow, and E. Ruoslahti. 1986. Platelet membrane glycoprotein IIb/IIla: member of a family of ArgGly-Asp-specific adhesion receptors. Science (Wash. DC). 231:1159-1162.

8. Phillips, D. R., I. F. Charo, L. V. Parise, and L. A. Fitzgerald. 1988. The platelet membrane glycoprotein Ilb-IIla complex. Blood. 71:831-843.

9. Poncz, M., R. Eisman, R. Heidenreich, S. M. Silver, G. Vilaire, S. Surrey, E Schwartz, and J. S. Bennett. 1987. Structure of the platelet membrane glycoprotein Ilb. Homology to the $\alpha$ subunit of the vitronectin and fibronectin receptors. J. Biol. Chem. 262:8476-8482.

10. Fitzgerald, L. A., B. Steiner, S. C. Rall, L. Shan-shan, and D. R. Phillips. 1987. Protein sequence of endothelial glycoprotein Illa derived from a cDNA clone. Identity with platelet glycoprotein IIla and similarity to integrin. J. Biol. Chem. 262:3936-3939.

11. Zimrin, A. B., R. Eisman, G. Vilaire, E. Schwartz, J. S. Bennett, and M. Poncz. 1988. Structure of platelet glycoprotein IIla. A common subunit for two different membrane receptors. J. Clin. Invest. 81:1470-1475.

12. Rosa, J.-P., P. F. Bray, O. Gayet, G. I. Johnston, R. G. Cook, M. A. Shuman, and R. P. McEver. 1988. Cloning of glycoprotein IIIa cDNA from human erythroleukemia cells and localization of the gene to chromosome 17. Blood. 72:593-600.

13. Ginsberg, M. H., J. Loftus, J. Rykwaert, M. Pierschbacher, R. Pytela, E. Ruoslahti, and E. F. Plow. 1987. Immunochemical and amino terminal sequence comparison of two cytoadhesins indicates they contain similar or identical $\beta$ subunits and distinct $\alpha$ subunits. J. Biol. Chem. 262:5437-5440.

14. Newman, P. J., Y. Kawai, R. R. Montgomery, and T. J. Kunicki. 1986. Synthesis by cultured human umbilical vein endothelial cells of two proteins structurally and immunologically related to platelet membrane glycoproteins IIb and IIIa. J. Cell Biol. 103:81-86.

15. Hynes, R. O. 1987. Integrins: a family of cell surface receptors. Cell. 48:549-554

16. Ruoslahti, E., and M. D. Pierschbacher. 1987. New perspectives in cell adhesion: RGD and integrins. Science (Wash. DC). 238:491-497.

17. Bray, P. F., G. Barsh, J-P. Rosa, X. Y. Luo, E. Magenis, and M. A. Shuman. 1988. Physical linkage of the genes for platelet membrane glycoproteins IIb and IIla. Proc. Natl. Acad. Sci. USA. 85:8683-8687.

18. Harfenist, E. J., M. A. Packham, and J. F. Mustard. 1988. Effects of the cell adhesion peptide, Arg-Gly-Asp-Ser, on responses of washed platelets from humans, rabbits and rats. Blood. 71:132-136.

19. D'Souza, S. E., M. H. Ginsberg, T. A. Burke, S. C. T. Lam, and E. F. Plow. 1988. Localization of an Arg-Gly-Asp recognition site within an integrin adhesion receptor. Science (Wash. DC). 242:91-94.

20. Gartner, T. K., and J. S. Bennett. 1985. The tetrapeptide analogue of the cell attachment site of fibronectin inhibits platelet aggregation and fibrinogen binding to activated platelets. J. Biol. Chem. 260:11891-11894.

21. Haverstick, D. M., J. F. Cowan, K. M. Yamada, and S. A. Santoro. 1985. Inhibition of platelet adhesion to fibronectin, fibrinogen and von Willebrand factor substrates by a synthetic tetrapeptide derived from the cell-binding domain of fibronectin. Blood. 66:946-952.

22. Fitzgerald, L. A., M. Poncz, B. Steiner, S. C. Rall, J. S. Bennett, and D. R. Phillips. 1987. Comparison of cDNA-derived protein sequences of the human fibronectin and vitronectin receptor $\alpha$-subunits and platelet glycoprotein IIb. Biochemistry. 26:8158-8165.

23. Suzuki, S., W. S. Argraves, H. Arai, L. R. Languino, M. D. Pierschbacher, and E. Ruoslahti. 1987. Amino acid sequence of the vitronectin receptor $\alpha$ subunit and comparative expression of adhesion receptor mRNAs. J. Biol. Chem. 262:14080-14085.

24. Argraves, W. S., S. Suzuki, H. Arai, K. Thompson, M. D. Pierschbacher, and $E$. Ruoslahti. 1987. Amino acid sequence of the human fibronectin receptor. J. Cell Biol. 105:1183-1190.

25. Aranout, M. A., S. K. Gupta, M. W. Pierce, and D. G. Tenen. 1988 Amino acid sequence of the alpha subunit of human leukocyte adhesion receptor Mol (complement receptor type 3). J. Cell Biol. 106:2153-2158.

26. Bogaert, T., N. Brown, and M. Wilcox. 1987. The drosophila PS2 antigen 
is an invertebrate integrin that, like the fibronectin receptor, becomes localized to muscle attachments. Cell. 51:929-940.

27. R. Pytela. 1988. Amino acid sequence of the murine Mac-1 $\alpha$ chain reveals homology with the integrin family and an additional domain related to von Willebrand factor. EMBO (Eur. Mol. Biol. Organ.) J. 7:1371-1378.

28. Corbi, A. L., L. J. Miller, K. O'Connor, R. S. Larson, and T. A. Springer. 1987. cDNA cloning and complete primary structure of the $\alpha$ subunit of a leukocyte adhesion glycoprotein, P150,95. EMBO (Eur. Mol. Biol. Organ.) J. 6:40234028.

29. Takada, Y., and M. E. Hemler. 1989. The primary structure of the VLA2/collagen receptor $\alpha$ subunit (platelet GPIa): homology to other integrins and the presence of a possible collagen-binding domain. J. Cell Biol. 109:397-407.

30. Kishimoto, T. K., K. O'Connor, A. Lee, T. M. Roberts, and T. A Springer. 1987. Cloning of the $\beta$ subunit of the leukocyte adhesion proteins: homology to an extracellular matrix receptor defines a novel supergene family. Cell. 48:681-690.

31. Cheresh, D. A., J. W. Smith, H. M. Cooper, and V. Quaranta. 1989. A novel vitronectin receptor integrin $\left(\alpha_{v} \beta_{x}\right)$ is responsible for distinct adhesive properties of carcinoma cells. Cell. 57:59-69.

32. Kajiji, S., R. N. Tamura, and V. Quaranta. 1989. A novel integrin (aEB4) from human epithelial cells suggests a fourth family of integrin adhesion receptors. EMBO (Eur. Mol. Biol. Organ.) J. 8:673-680.

33. Sosnoski, D. M., B. S. Emanuel, A. L. Hawkins, P. van Tuinen, D. H Ledbetter, R. L. Nussbaum, F.-T. Kaos, E. Schwartz, D. Phillips, J. S. Bennett, et al. 1988. Chromosomal localization of the genes for vitronectin and fibronectin receptors $\alpha$ subunits and of platelet glycoproteins IIb and IIIa. J. Clin. Invest. 81:1993-1998.

34. Marlin, S. D., C. C. Morton, D. C. Anderson, and T. A. Springer. 1986 LFA-1 immunodeficiency disease: definition of the genetic defect and chromosomal mapping of the $\alpha$ and $\beta$ subunits of the lymphocyte function-associated antigen 1(LFA-1) by complementation in hybrid cells. J. Exp. Med. 164:855867.

35. George, J. N., J. P. Caen, and A. T. Nurden. 1990. Glanzmann thrombasthenia: the spectrum of clinical disease. Blood. 75:1383-1395.

36. Nurden, A. T., D. Didry, N. Kieffer, and R. P. McEver. 1985. Residual amounts of glycoproteins IIb and IIIa may be present in the platelets of most patients with Glanzmann's thrombasthenia. Blood. 65:1021-1024.

37. Coller, B. S., U. Seligsohn, and P. A. Little. 1987. Type I Glanzmann thrombasthenia patients from the Iraqi-Jewish and Arab population in Israel can be differentiated by platelet glycoprotein IIIa immunoblot analysis. Blood. 69:1696-1703.

38. Nurden, A. T., J.-P. Rosa, D. Fournier, C. Legrand, D. Didry, A. Parquet, and D. Pidard. 1987. A variant of Glanzmann's thrombasthenia with abnorma glycoprotein IIb-IIIa complexes in the platelet membrane. J. Clin. Invest. 79:962969.

39. Jung, S. M., N. Yoshida, N. Aoki, K. Tanoue, H. Yamakaze, and M Moroi. 1988. Thrombasthenia with an abnormal platelet membrane glycoprotein Ilb of different molecular weight. Blood. 71:915-922.

40. O’Toole, T. E., J. C. Loftus, E. F. Plow, A. A. Glass, J. R. Harper, and M. H. Ginsberg. 1989. Efficient surface expression of platelet GPIIb-IIIa requires both subunits. Blood. 74:14-18.

41. Newman, P. J., R. W. Allen, R. A. Kahn, and T. J. Kunicki. 1985. Quantitation of membrane glycoprotein IIIa on intact human platelets using the monoclonal antibody, AP-3. Blood. 65:227-232.

42. Loftus, J. C., E. F. Plow, A. L. Frelinger III, S. E. D'Souza, D. Dixon, J. Lacy, J. Sorge, and M. H. Ginsberg. 1987. Molecular cloning and chemical synthesis of a region of platelet glycoprotein IIb involved in adhesive function. Proc. Natl. Acad. Sci. USA. 84:7114-7118.

43. Cheresh, D. A. 1987. Human endothelial cells synthesize and express an Arg-Gly-Asp-directed adhesion receptor involved in attachment to fibrinogen and von Willebrand factor. Proc. Natl. Acad. Sci. USA. 84:6471-6475.
44. Cheresh, D. A., and R. C. Spiro. 1987. Biosynthetic and functional properties of an Arg-Gly-Asp-directed receptor involved in human melanoma cell attachment to vitronectin, fibrinogen, and von Willebrand factor. J. Biol. Chem. 262:17703-17711.

45. Newman, P. J., M. C. Berndt, J. Gorski, G. C. White II, S. Lyman, C Paddock, and W. A. Muller. 1990. PECAM-1 (CD31) cloning and relation to adhesion molecules of the immunoglobulin gene superfamily. Science (Wash DC). 247:1219-1222.

46. Newman, P. J., J. Gorski, G. C. White II, S. Gidwitz, C. J. Cretney, and R. H. Aster. Enzymatic amplification of platelet-specific messenger RNA using the polymerase chain reaction. J. Clin. Invest. 82:739-743.

47. Poncz, M., D. Solowiejczyk, B. Harpel, Y. Mory, E. Schwartz, and S. Surrey. 1982. Construction of human gene libraries from small amounts of peripheral blood: analysis of $\beta$-like globin genes. Hemoglobin. 6:27-37.

48. Heidenreich, R., R. Eisman, K. Delgrosso, S. Surrey, J. S. Bennett, E. Schwartz, and M. Poncz. 1990. The organization of the gene for platelet glycoprotein IIb. Biochemistry. 29:1232-1244.

49. Maniatis, T., E. F. Fritsch, and J. Sambrook. 1982. Molecular Cloning: A Laboratory Manual. Cold Spring Harbor Laboratory, Cold Spring Harbor, NY. 545 pp.

50. Semenza, G. L., K. Delgrosso, M. Poncz, P. Malladi, E. Schwartz, and S. Surrey. 1984. The silent carrier allele: $\beta$ thalassemia without a mutation in the $\beta$-globin gene or its immediate flanking region. Cell. 39:123-128.

51. Poncz, M., D. Solowiejczk, M. Ballantine, E. Schwartz, and S. Surrey. 1982. Nonrandom DNA sequence analysis in bacteriophage $M 13$ by the dideoxy chain-termination method. Proc. Natl. Acad. Sci. USA. 79:4298-4302.

52. Sanger, F., S. Nicklen, and A. A. Coulson. 1977. DNA sequencing with chain-terminating inhibitors. Proc. Natl. Acad. Sci. USA. 74:5463-5468.

53. Lyman, S., R. H. Aster, G. P. Visentine, and P. J. Newman. 1990. Polymorphism of human platelet membrane glycoprotein IIb associated with the Bak $^{2} /$ Bak $^{b}$ alloantigen system. Blood. 75:2343-2348.

54. Coller, B. S., U. Seligsohn, D. A. Cheresh, and L. E. Scudder. 1989. Platelet vitronectin receptor $(\mathrm{VnR})$ heterogeneity among the Glanzmann thrombasthenia (GT) patients in Israel. Blood. 74:208a.

55. Newman, P., U. Seligsohn, S. Lyman, M. Poncz, and B. S. Coller. 1990. The molecular basis of Glanzmann thrombasthenia in the Iraqi-Jewish and Arab populations in Israel. Clin. Res. 38:467a.

56. Coller, B. S., D. A. Cheresh, E. Asch, and U. Selighsohn. 1990. Platelet vitronectin receptor expression differentiates Iraqi-Jewish from Arab patients with Glanzmann thrombasthenia in Israel. Blood. In press.

57. Schmid, C. W., and W. R. Jelinek. 1982. The Alu family of dispersed repetitive sequences. Science (Wash. DC). 216:1065-1070.

58. Nienhuis, A. W., and T. Maniatis. 1987. Structure and expression of globin genes in eyrthroid cells. In The Molecular Biology of Blood Diseases. G. Stamatoyannopoulos, A. W. Nienhuis, P. Leder, and P. W. Majerus, editors. W. B. Saunders Co., Philadelphia. 28-65.

59. Bray, P. F., and M. A. Schuman. 1990 . Identification of an abnormal gene for the GPIIla subunit of the platelet fibrinogen receptor resulting in Glanzmann's thrombasthenia. Blood. 75:881-888.

60. Duperray, A., A. Toesch, R. Berthier, E. Chagnon, P. Frachet, G. Uzan, and G. Marguerie. 1989. Biosynthesis and assembly of platelet GPIIb-IIIa in human megakaryocytes: evidence that assembly between pro-GPIIb and GPIIla is a prerequisite for expression of the complex on the cell surface. Blood. 74:16031611

61. Lam, S. C.-T., E. F. Plow, S. E. D'Souza, D. A. Cheresh, and A. L. Frelinger III. 1989. Isolation and characterization of a platelet membrane protein related to the vitronectin receptor. J. Biol. Chem. 264:3742-3749.

62. Lawler, J., and R. O. Hynes. 1989. An integrin receptor on normal and thrombasthenic platelets which binds thrombospondin. Blood. 74:2022-2027. 